\title{
THE IMPACT OF VAILLANCOURT V. THE QUEEN ON CANADIAN CRIMINAL LAW
}

\author{
ISABEL GRANT*
}

The 1987 Supreme Court decision of Vaillancourt struck down s.213(d) of the Criminal Code, finding that the constructive murder provision violated ss. 7 and 11 (d) of the Charter. This paper looks at how the courts have since applied Vaillancourt to other sections of the Criminal Code, particularly the remaining murder provisions. The analysis is based largely on a consequence-circumstance distinction, where legally relevant consequences involve the harm caused by the accused and the circumstances refer to conditions that must be shown to exist before there can be a conviction. However, because murder is a unique crime with a "special stigma" attached to it, courts will not allow an objective standard of mens rea to form the basis of a murder conviction.
En se prononçant dans la cause Vaillancourt (1987), la Cour suprême, ayant conclu que la disposition de meurtre par interprétation violait les articles 7 et $I I(d)$ de la Charte, a annule l'article 213(d) du Code criminel. L'auteur examine comment les tribunaux ont depuis lors appliqué cette décision aux autres articles du Code criminel, plus particulièrement en ce qui concerne les dispositions relatives au meurtre. L'analyse s'appuie surtout sur la distinction conséquence-circonstance, où les conséquences juridiquement pertinentes intéressent le prejudice causé par l'accusé et les circonstances, les conditions à prouver avant toute déclaration de culpabilité. Néanmoins, parce que le meurtre est un crime unique, entaché de "stigmates particuliers," les tribunaux ne permettent pas qu'une norme de mens rea objective constitue la base d'une déclaration de culpabilité pour meurtre.

\section{TABLE OF CONTENTS}

I. INTRODUCTION

II. THE DECISION IN VAILLANCOURT V. THE QUEEN . . . . .

III. POST-VAILLANCOURT DEVELOPMENTS ............

A. THE IMPLICATIONS OF VAILLANCOURT FOR CRIMINAL CODE PROVISIONS OTHER THAN MURDER

1. The Consequence/Circumstance Distinction ............

2. Consequences and Circumstances: The Post-Vaillancourt Case Law Outside the Context of Murder ..............

B. THE IMPLICATIONS OF VAILLANCOURT FOR THE CRIME OF MURDER

1. Section 213(a)-(c)

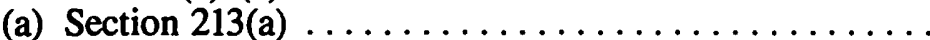

(b) Section 213(b)

(c) Section 213(c)

(d) Impact of Finding Section 213 Invalid . . . . . . . .

2. Parties to Murder .................... 458

3. First-Degree Murder ................... 461

(a) Section $214(4)(a) \ldots \ldots \ldots \ldots \ldots \ldots \ldots \ldots \ldots, 462$

(b) Section 214(5) ...................... 464

IV. CONCLUSION

* Assistant Professor, Faculty of Law, University of British Columbia.

This is the text of a paper which was presented at the October 1989 meeting of the B.C. Branch of the Criminal Justice Subsection of the Canadian Bar Association. I would like to thank Tamara Hunter, Bruce MacDougall and Bruce Ziff for their many helpful comments on this paper, and Lise Kirchner for her research assistance. Special thanks to Masaru Kohno for his help in editing this paper. 
[VOL. XXVIII, NO. 2

\section{INTRODUCTION}

After Vaillancourt v. the Queen' was decided on December 3, 1987, many academic commentators predicted that the decision would have a drastic impact on criminal law. ${ }^{2}$ To date, these predictions have not been realized and the effects of the decision have been largely limited to the crime of murder.

This paper will review the decision in Vaillancourt and the extent to which it has influenced Canadian criminal law. The paper begins with a brief summary of the decision and then moves on to consider two aspects of the post-Vaillancourt developments. First, I will examine the implications of Vaillancourt for provisions in the Criminal Code other than murder. Secondly, I will consider the implications of Vaillancourt for the remaining murder provisions in the Criminal Code. The purpose of this paper is a narrow one: to describe the developments since Vaillancourt and to attempt to bring some order to an otherwise confusing area of the law.

\section{THE DECISION IN VAILLANCOURT V. THE QUEEN}

In Vaillancourt the Supreme Court of Canada struck down s. 213(d) ${ }^{3}$ of the Criminal Code because it was contrary to ss. 7 and 11(d) of the Canadian Charter of Rights and Freedoms. ${ }^{4}$ Section 213 of the Criminal Code contains Canada's constructive murder provisions and punishes as murder deaths which occur in the course of committing (or attempting to commit) specified indictable offences such as robbery and sexual assault. Section 213(d) was the harshest subsection in s. 213. That section 213(d) stated that an individual who causes the death of a person while committing or attempting to commit one of the enumerated offences is guilty of murder if:

(d) he uses a weapon or has it upon his person

(i) during or at the time he commits or attempts to commit the offence, or

1. $R$ v. Vaillancourt, [1987] 2 S.C.R. 636 , (1988) 60 C.R. (3d) 289,39 C.C.C. (3d) 118 . [hereinafter Vaillancourt cited to S.C.R.] The companion decision to Vaillancourt is $R$ v. Laviolette [1987]2 S.C.R. 667.

2. See for example Bruce Archibald, "The Constitutionalization of the General Part of Criminal Law" (1988) 67 Can. Bar Rev. 403; Isabel Grant " $R$ v. Vaillancourt: The Constitutionalization of Mens Rea" (1988) 22 U.B.C.L. Rev. 369; Ross McNab "Case Comment: $R$ v. Vaillancourt" (1988) Queen's Law J. 208; Peter MacKinnon "Case Comment: Vaillancourt v. The Queen" (1988) 67 Can. Bar Rev. 350.

3. Criminal Code R.S.C., 1970 c. C-34 now s. 230 of the Criminal Code R.S.C. 1985, c. C-46. Throughout this paper I will be referring to the Code provisions by their section numbers under the Criminal Code R.S.C. 1970, c. C-34.

$$
\begin{array}{lc} 
& \text { Concordance } \\
\text { R.S.C. 1970, c. C-34 } & \text { R.S.C. } 1985, \text { c. C-46 } \\
\text { s. } 21 & \text { s. } 21 \\
212 & 229 \\
213 & 230 \\
214 & 231 \\
245 & 268 \\
613 & 686 \\
642 & 745
\end{array}
$$

Much of the description of the decision in this part was taken from Isabel Grant, " $R$. v. Vaillancourt: The Constitutionalization of Mens Rea", supra, note 2.

4. Part I of the Constitution Act, 1982, being Schedule B of the Canada Act, 1982. 
(ii) during or at the time of his flight after committing or attempting to commit the offence, and death ensues as a consequence.

The only mens rea required for a conviction is the intent to commit the underlying offence and the intent to use or have upon one's person a weapon. It is irrelevant whether or not an accused intended to cause bodily harm. The only cases caught by s. 213(d) which could not have been covered by other murder provisions in the Code were those in which the accused could not reasonably have foreseen that death was likely to ensue.

The stage was set for the constitutional challenge in Vaillancourt by the Supreme Court's decision in Reference Re Section 94(2) of the Motor Vehicle Act. ${ }^{5}$ In that case the Court held that absolute liability violates the principle of fundamental justice that no one be convicted of an offence without some level of moral fault. When absolute liability is coupled with a deprivation of liberty, there is a violation of s. 7 of the Charter. The Motor Vehicle Reference did not specify what level of mens rea was required, although one passage of the judgment suggested that a strict liability due diligence defence would have saved the legislation in issue. ${ }^{6}$

Writing for himself and three other judges in Vaillancourt, Lamer J. concluded that s. 213(d) (and at least the rest of s.213) ${ }^{7}$ violates ss.7 and 11(d) of the Charter. ${ }^{8}$ Section 7 mandates that there be at least objective foresight for every part of the actus reus of murder. Section 11(d) requires that the Crown prove every essential element of an offence beyond a reasonable doubt. Hence s. 11(d) is violated if a conviction can occur even when the jury has a reasonable doubt as to whether the accused ought to have foreseen the likelihood of death. Lamer J. limited himself to holding that it is a principle of fundamental justice that there be at least objective foresight for every element of the actus reus of murder. This means that "absent proof beyond a reasonable doubt of at least objective foreseeability, there surely cannot be a murder conviction'.. Section 213(d) violated this principle because the Crown did not need to prove any foresight, objective or subjective, with regard to the consequence of death.

Having found a violation of both ss. 7 and 11(d), Lamer J. turned to s. 1 of the Charter to see if s. 213(d) could be upheld as a reasonable limit. Applying the Oakes criteria he concluded that, while the objective of deterring the commission of crimes with weapons was compelling, the means by which Parliament had achieved this objective unduly impaired Charter rights. ${ }^{10}$

5. Reference Re: Section 94(2) of the Motor Vehicle Act, R.S.B.C. 1979, c. 288, [1985] 2 S.C.R. 486, (1985) 24 D.L.R. (4th) 536, 23 C.C.C. (3d) 289.

6. Ibid., at 521 (S.C.R.).

7. LamerJ. indicated that all of $s .213$ violates $s .7$ even though only subsection (d) was before the Court. The s. 1 analysis, however, is limited to s. 213(d) and thus the holding in the case is only that s. 213(d) violates the Charter.

8. Section 7 of the Charter states:

Everyone has the right to life, liberty and security of the person and the right not to be deprived thereof except in accordance with the principles of fundamental justice.

Section 11(d) of the Charter states:

Any person charged with an offence has the right . . . to be presumed innocent until proven guilty according to law in a fair and public hearing by an independent and impartial tribunal.

9. Vaillancourt, supra, note 1 at 654 .

10. $R$ v. Oakes, [1986] i S.C.R. 103, (1986) 26 D.L.R. (4th) 200,24 C.C.C. (3d) 321. 
It is not necessary to convict of murder persons who did not intend or foresee the death and who could not even have foreseen the death in order to deter others from using or carrying weapons. If Parliament wishes to deter the use or carrying of weapons, it should punish the use or carrying of weapons. A good example of this is the minimum imprisonment for using a firearm in the commission of an indictable offence under s. 83 of the Criminal Code."

While the narrow finding of the case is that the Crown must prove at least objective mens rea for every element of the actus reus of murder, Lamer J. hinted that subjective mens rea may be required for every element of murder. He noted that murder is the most serious crime in our society with a corresponding "special stigma". ${ }^{12}$ The crime of murder is defined by reference to its consequence, i.e. death, and thus there must be some special mental element to correspond with that consequence. He stated:

I am presently of the view that it is a principle of fundamental justice that a conviction for murder

cannot rest on anything less than proof beyond a reasonable doubt of subjective foresight. ${ }^{13}$

However, Lamer was not willing to base his findings of invalidity on this view because, as he noted repeatedly in the judgment, he did not want to strike down s.212(c) when it was not before the Court. ${ }^{14}$

Mr. Justice McIntyre was alone in upholding s. 213(d), expressing his usual reluctance to interfere with the policy judgments of Parliament. He noted that no objection would have been taken to s. 213(d) if Parliament had classified the offence as manslaughter or a killing during the commission of an offence, rather than as murder. The mere fact that Parliament had labelled the crime murder was an insufficient reason for invalidating s. 213(d).

Thus we have the first Supreme Court of Canada decision striking down a substantive Criminal Code offence under the Charter. The ambiguity of Lamer J.'s majority judgment has left unresolved many questions about mens rea and the Charter. Is subjective mens rea a requirement for murder? Is murder unique because of the special "stigma" attached to it, or will the Court require subjective mens rea for most serious crimes? It is necessary to look to the post-Vaillancourt developments to address some of these unanswered questions.

\section{POST-VAILLANCOURT DEVELOPMENTS}

A broad overview of the early judicial developments since the 1987 Vaillancourt decision reveals that the effects of Vaillancourt upon Canadian criminal law have been limited almost entirely to the context of murder. Although the courts have considered the principles enunciated in the case in relation to other Criminal Code provisions, they have been reluctant to extend the rationale to other crimes against the person and have distinguished murder as a unique offence because of the special "stigma" and sentence attached to conviction. I will begin by discussing the cases

11. Vaillancourt, supra, note 1 at 660.

12. Ibid., at 653.

13. Ibid., at 654 .

14. Section 212 (c) contains Canada's only "negligent" murder provision. If an accused who is engaged in an unlawful object does anything that he or she "ought to know" is likely to cause death and death results, he or she is guilty of murder even if he or she wanted to effect the purpose without causing death. In an earlier judgment Lamer J. limited the scope of this provision $(R$ v. Vasil, [1981] 1 S.C.R. 469, (1981) 121 D.L.R. (3d) 41, 58 C.C.C. (2d) 97 ). The accused in Vaillancourt, ibid., could probably have been convicted under a combination of s. 21(2) and s. 212(c). 
which involve challenges to Code provisions outside the murder context to illustrate the general reluctance on the part of courts to require mens rea for the harmful consequences of criminal activity.

\section{A. THE IMPLICATIONS OF VAILLANCOURT FOR CRIMINAL CODE PROVISIONS OTHER THAN MURDER}

Several sections of the Criminal Code have been challenged as a result of the ruling in Vaillancourt. In general, challenges outside the murder context have met with limited success as courts have found ways to distinguish Vaillancourt and the crime of murder as unique. One pattern that does seem to be emerging, which can help differentiate the successful from the unsuccessful Charter challenges in this area, is based on the distinction between consequence and circumstance crimes. The courts seem to be distinguishing between mens rea for the circumstances which make conduct criminal and mens rea for the harmful consequences of criminal activity. The courts are not making this distinction openly, but it does describe the results in several of the recent cases.

\section{The Consequence/Circumstance Distinction}

Legally relevant circumstances refer to conditions in the environment which must be shown to exist before an accused can be convicted of a crime. Mens rea for a circumstance refers to whether or not the accused knew of the existing state of affairs that made his or her conduct criminal. For example, in the crime of sexual assault, the Crown must prove the absence of consent as a legally relevant circumstance. The mens rea issue is whether the accused knew that the victim was not consenting. The accused person does not cause the circumstance to exist but, if he or she knows of its existence and acts nonetheless, we assign criminal liability.

The term legally relevant consequences, as used in this paper, refers to the harm brought about by the accused in the commission of his or her offence. ${ }^{15}$ Thus, an accused changes the environment in a negative way by bringing about a certain consequence. The mens rea issue is whether the accused has to intend or foresee the particular consequence. In the crime of assault causing bodily harm, for example, the Crown has to prove that the victim suffered the consequence of bodily harm. However, the courts have held that the Crown need not prove that the accused intended to cause bodily harm. ${ }^{16}$

The issues addressed in the Motor Vehicle Reference and in Vaillancourt illustrate this distinction. The Motor Vehicle Reference involved the offence of driving while one's licence is suspended. The issue was whether there had to be some mental state vis à vis the fact of suspension - the circumstance which made the conduct criminal. Without this circumstance, the conduct would not have been blameworthy. Vaillancourt, on the other hand, involved a challenge to a criminal offence

15. This analysis is limited to consequence crimes where the consequence describes the amount of harm caused by an individual's conduct. I am not addressing crimes in which the conduct itself is defined in terms of the consequence, and where it is the fraudulent nature of the conduct, not the consequence per se, that is harmful. See, for example, obtaining food and lodging by fraud in s. 322 of the Criminal Code (now s. 364).

16. $R$ v. Brooks (1988), 41 C.C.C. (3d) 157 (B.C.C.A.) [hereinafter Brooks cited to C.C.C.]. 
which required no mental state for the consequence that defined the offence. Thus it is a mistake to conceptualize Vaillancourt as merely an extension of the Motor Vehicle Reference since the two cases dealt with different aspects of mens rea.

Because of the heightened stigma and the mandatory sentence associated with murder, Lamer J. held in Vaillancourt that some level of mens rea (even if only objective foresight) is required with regard to the consequence of death. However, he made a point of limiting his decision to the unique crime of murder. In the following ambiguous passage, he opens up the possibility that the mens rea requirement for consequences may not always be as stringent as the mens rea required for the criminal act: ${ }^{17}$

It may well be that, as a general rule, the principles of fundamental justice require proof of a subjective mens rea with respect to the prohibited act, in order to avoid punishing "the morally innocent". . . In any event, this case involves criminal liability for the result of an intentional criminal act, and it is arguable that different considerations should apply to the mental element required with respect to that result. There are many provisions in the Code requiring only objective foreseeability of the result or even only a causal link between the act and the result. As I would prefer not to cast doubt on the validity of such provisions in this case, I will assume, but only for the purposes of this appeal, that something less than subjective foresight of the result may, sometimes, suffice for the imposition of criminal liability for causing that result through intentional criminal conduct.

In this passage Lamer J. refers to a difference between the mens rea for causing a result and the mens rea for "the prohibited act", implying that causing a result may require a lesser level of mens rea. He says nothing about mens rea for circumstances that make conduct criminal. I would suggest that such circumstances can best be characterized as part of "the prohibited act" since they are often what makes the act criminal. Acts themselves may be morally neutral and become criminal only in the context of the surrounding circumstances. If this characterization is correct, then courts may require a higher level of mens rea for circumstances than for the consequences of criminal activity.

Why would Lamer J. suggest that a lesser level of mens rea may be sufficient for causing a result? There are at least two possible reasons for requiring a lower level of mens rea for a consequence of criminal activity than for a circumstance which makes the conduct criminal. First, a circumstance may be the only factor that makes conduct criminal and thus knowledge of that circumstance may be the only measure of moral blameworthiness. For example, without lack of consent a sexual assault might not be blameworthy; but for the age of the complainant, statutory rape would not be criminal; and getting married for a second time is only criminal if a previous valid marriage still exists. ${ }^{18}$ With a consequence crime, however, there is often some level of moral blameworthiness such that even if the

17. Vaillancourt, supra, note 1 at 653 [emphasis original]. For a more detailed discussion of this passage see Isabel Grant " $R$ v. Vaillancourt: The Constitutionalization of Mens Rea", supra, note 2.

18. This argument only applies to crimes in which the relevant circumstance is the only factor making the conduct criminal. Some circumstance crimes in the Criminal Code do have included offences such that, even if an accused has no mens rea for the relevant circumstance, he or she can still be convicted of an included offence. [See for example, the offence of theft from the mail in s. 314(1)(a) of the Criminal Code (now s. 356(1)(a)). If an accused had no mens rea for the circumstance of the mail being deposited but not delivered, he or she can still be convicted of theft.] Similarly, some offences have more than one circumstance such that if the accused has no mens rea for one of them, the conduct may still be morally blameworthy. [For example, an accused charged with assaulting a peace officer in the course of his or her duties under s. 246 of the Criminal Code (now s. 270) who did not know the status of the victim, could still be convicted of assault under s. 245 (now s. 266).] 
specific consequence is unintended, there is still some level of guilty mind. An accused charged with assault causing bodily harm, who had no mens rea for the causing of bodily harm, may still have had the mens rea for assault. ${ }^{19}$

Secondly, the causing of a legally relevant consequence is a harm done to society that may, in itself, be worthy of punishment even if the accused did not intend the full amount of harm. Our courts have acknowledged that the degree of harm caused by an offence is a relevant consideration for assessing criminal responsibility. ${ }^{20}$ For example, we punish attempts less severely than we punish completed offences, even though the mens rea requirement for an attempt is the same (or greater) than that of the completed offence. What makes the completed offence worthy of greater punishment is the harm caused by its completion. ${ }^{21}$ Increasing punishment on the basis of the amount of harm caused by an offender involves making choices about who should bear the risk of criminal conduct. If an individual chooses to undertake criminal activity and cause some harm, he or she must bear the risk that more harm than intended will result.

\section{Consequences and Circumstances: the Post Vaillancourt Case Law Outside the Context of Murder}

In defining the level of mens rea required for a consequence crime, a court must first determine whether there is any mental element required with regard to causing harm and, if so, whether objective or subjective mens rea is the minimum requirement. As will be seen below, the courts seem to be developing a continuum with respect to the mens rea for consequence crimes. In the less serious offences, the courts are requiring no mental element for the consequences of criminal conduct. In serious offences other than murder, such as manslaughter, the courts seem to agree that some level of mens rea is required but there is uncertainty as to whether that mens rea must be objective or subjective. In the context of murder, our most serious offence, the courts are clearly moving towards requiring subjective mens rea for the consequence of death in all cases. In circumstance crimes, on the other hand, there seems to be an assumption that some level of mens rea, even if only negligence, is always required for the circumstance.

19. Professor Colvin refers to such offences as crimes of "partial" mens rea: "offences requiring a state of mind to be proved with respect to some but not all of the conduct elements." Eric Colvin, Principles of Criminal Law (Toronto: Carswell, 1986) at 44.

20. In holding that there was no mens rea required for causing bodily harm in the crime of assault causing bodily harm, Mr. Justice Macdonald stated in Brooks, supra, note 16 at 161: "Our criminal law has always recognized that the consequences of an unlawful act may affect the degree of culpability." In $R$ v. Tutton and Tutton [(1989) 48 C.C.C. (3d) 129 (S.C.C.) [hereinafter Tutton cited to C.C.C.]]. Mr. Justice McIntyre supported an objective test of mens rea for causing death by criminal negligence and stressed the need to punish negligent conduct that leads to social harm:

. . . what is sought to be restrained by punishment under s. 202 of the Code is conduct, and its results. What is punished, in other words, is not the state of mind but the consequences of mindless action (at 139).

21. It could be argued that punishing individuals for causing harm, irrespective of an intent to cause that harm, fails to distinguish adequately between the of fender who meant to cause the precise harm which resulted and the offender who meant to cause less harm than actually ensued. 
In $R$ v. Scharf, ${ }^{2}$ the Manitoba Court of Appeal considered the issue of whether an intent to endanger life or, in the alternative, at least objective foreseeability of harm that endangers life, is an essential element of the crime of assault endangering the life of a person (aggravated assault under s. 245(1) now s. 268(1)). The Court refused to apply the Vaillancourt decision in the context of assault and held that objective foreseeability of serious harm is not an essential element of the offence. Although the severity of the assault charge is determined by the consequences of the assault, ${ }^{23}$ the nature and extent of the consequences do not have to be intended or a reasonably foreseeable result of the assault. The mens rea for every level of assault is simply the general intent to do the acts which constitute the assault no matter how severe the consequences.

$R$ v. Brooks ${ }^{24}$ involved a constitutional challenge to s. $245.1(1)(b)$ of the Criminal Code, the offence of assault causing bodily harm. Basing his argument on Vaillancourt, the accused contended that s. 245.1(1)(b) must have as an essential element the intention to cause bodily harm. It was argued that the absence of a mens rea requirement for the consequences of the assault violates ss. 7 and 11(d) of the Charter because a jury could convict even if it had a reasonable doubt as to whether the accused ought to have foreseen that bodily harm was a likely result of the assault. The British Columbia Court of Appeal held that the requirement of a mere causal link between the act and the result is sufficient to satisfy the principles of fundamental justice and the presumption of innocence. The Court distinguished Vaillancourt by saying that the stigma of assault causing bodily harm is not comparable to the stigma of murder and thus does not warrant the level of constitutional protection required in the murder context.

In two long awaited decisions dealing with the mens rea of criminal negligence, the Supreme Court of Canada was divided on the issue of the constitutional level of mens rea required for the consequence of death in the crime of causing death by criminal negligence. The issue here was not whether mens rea was required for the consequence: the whole Court agreed that some level of mens rea was required. The question was whether the test for mens rea should be objective or subjective. In $R$ v. Tutton and Tutton, the Court split 3:3 as to whether causing death by criminal negligence involves an objective or a subjective test for mens rea. ${ }^{25}$ Wilson J., writing for the three members of the Court who favoured subjective mens rea, indicated that an objective test would bring into question the constitutional validity of the section. McIntyre J. (L'Heureux-Dube J. concurring) held that the test was objective. Lamer J., who agreed that an objective test should be employed, wrote short concurring reasons to stress that individual characteristics should be

22. R v. Scharf, (1988) 52 Man. R. (2d) 269 (C.A.).

23. The Criminal Code provides three forms of assault: common assault, assault causing bodily harm and aggravated assault. These assault offences are graduated from least serious to most serious according to the severity of the consequences of the assault.

24. Brooks, supra, note 16.

25. Tutton, supra, note 20 . See also the companion case of $R$ v. Waite (1989), 48 C.C.C. 1. [hereinafter Waite cited to C.C.C.].

The Supreme Court of Canada will soon have an opportunity to reconsider the issue of mens rea for criminal negligence when it hears an appeal from the British Columbia Court of Appeal of a conviction of criminal negligence causing bodily harm in $R$ v. Sullivan and Lemay (1988), 65 C.R. (3d) 256 (B.C.C.A.). It is likely that the Court will limit its decision to the crime of criminal negligence. 
taken into account when applying the objective test. As to the constitutionality of an objective test (however subjectified), Lamer J. stated: $:^{26}$

I should finally mention that in this case, the constitutionality of s. 205(5)(b) was not an issue. Indeed, assuming without now deciding that it is a principle of fundamental justice that knowledge of a likely risk or deliberate ignorance there of (foresight or willful blindness) is an essential element of the offense of manslaughter, the issue as to whether proof of the substituted element of "criminal negligence" as defined by Parliament and interpreted by this Court satisfies the test set out in $R$ v. Vaillancourt, [1987] 2 S.C.R. 636, does not arise. I, therefore, do not by my concurrence feel precluded or limited when addressing such a constitutional challenge, of course, if and when called upon to do so.

Lamer J. was referring to the following passage from Vaillancourt where he indicated that proof of one element may substitute for proof of a constitutionally required element: ${ }^{27}$

The legislature, rather than simply eliminating any need to prove the essential element, may substitute proof of a different element. In my view, this will be constitutionally valid only if upon proof beyond reasonable doubt of the substituted element it would be unreasonable for the trier of fact not to be satisfied beyond reasonable doubt of the existence of the essential element. If the trier of fact may have a reasonable doubt as to the essential element notwithstanding proof beyond a reasonable doubt of the substituted element, then the substitution infringes ss. 7 and $11(d)$.

In Tutton, Lamer J. seems to be suggesting that while subjective mens rea with regard to the risk of death may be a constitutionally required element of manslaughter, the application of a personalized objective test may be a valid substitution for such an element. However, this objective test would only satisfy the Vaillancourt test if no reasonable jury, on proof of the objective nature of the conduct, could have a reasonable doubt about subjective mens rea. It seems unlikely that this test could always be met. Lamer J. himself earlier in his judgment stated that if an individualized objective test is used $:^{28}$

The adoption of a subjective or of an objective test will, in practice, nearly if not always produce the same result.

It remains to be seen if "nearly if not always" is constitutionally adequate. ${ }^{29}$

Courts may be more willing to find Charter violations where the legislative provision removes mens rea for the circumstance which make the conduct criminal. In Stevens v. the Queen ${ }^{30}$ the Supreme Court of Canada was asked to address the constitutional validity of what was then $\mathrm{s.} 146$ which made it an offence for a male to have sexual intercourse with a female under the age of fourteen, regardless of whether he knew how old the female was. In other words, the section

26. Ibid., at 143.

27. Vaillancourt, supra, note 1 at 656 .

28. Tutton, supra, note 20 , at 143 , emphasis added. Consider, for example, the facts of Waite, supra, note 25 the companion case of Tutton. The accused, who had been drinking, killed four young people and injured a fifth while deliberately driving down the wrong side of the road "playing chicken" with the young participants of a hayride. The jury acquitted the accused of causing death by criminal negligence apparently because it did not find the subjective mens rea which the trial judge said was required. Instead, the jury convicted Waite of dangerous driving. There is no question that Mr. Waite's conduct showed a marked and significant departure from that of a reasonably prudent person regardless of how many individualized factors one considers. Waite may be one of those rare cases where it does matter whether the test is objective or subjective.

29. It is unclear why Lamer J. did not just adopt a subjective test. The distinction between manslaughter and murder has always focussed on the mens rea for the consequence of death and it is possible that Lamer J. is trying to maintain this distinction.

30. [1988] I S.C.R. 1153, (1988) 64 C.R. (3d) 297, 41 C.C.C. (3d) 193. 
removed the mens rea requirement from the circumstance that defined the very nature of the offence - the age of the complainant.

The majority of the Court never reached the mens rea issue because it held that the Charter did not apply because the act of intercourse took place before April 17, 1982. However, Madam Justice Wilson, in dissent on the retrospectivity issue, found that the denial of a mistake of fact defence violated s. 7 of the Charter. Wilson $\mathrm{J}$. categorized the offence as being akin to absolute liability and followed the Motor Vehicle Reference in holding that absolute liability coupled with imprisonment violates s.7. Relying on Lamer J.'s judgment in the Motor Vehicle Reference, she held that at least a due diligence defence must be open to the accused. In other words, the accused must be given the opportunity to show that he was not negligent. ${ }^{31}$

Wilson J.'s minority judgment on the issue of mens rea for the age of the complainant under s. 146 was followed in a recent decision of the Alberta Court of Appeal. In $R$ v. Brooks, ${ }^{32}$ the Court held that the statutory denial of the mistake of fact defence violated s. 7 of the Charter. ${ }^{33}$ The Court purported to be basing its decision on the principle enunciated in Vaillancourt that the principles of fundamental justice require some level of mens rea for every essential element of an offence. Interestingly, the Court did not even mention the Motor Vehicle Reference (which was the basis of Wilson J's decision in Stevens) nor did it distinguish between mens $r e a$ as to the consequences of criminal activity (the issue in Vaillancourt) and mens rea as to circumstances (the issue in the Motor Vehicle Reference and Stevens). Instead, the Alberta Court of Appeal generalized the principle in Vaillancourt and applied it to mens rea for any essential element of the crime. The analysis is not very helpful since it does not tell us how to distinguish essential from non essential elements of a crime. ${ }^{34}$

Courts must elucidate more openly why they require mens rea for all elements of some offences and not for others. It is not sufficient to state the conclusion that some elements are essential and others are not, without providing any criteria for identifying which elements fall into which category. If what the courts are doing is requiring less mens rea for the harmful consequences of otherwise criminal conduct or, as in the criminal negligence context, recognizing the importance of punishing individuals who cause more harm regardless of mens rea, then this should be done expressly.

31. The majority in Stevens, Ibid., expressed no view on Wilson J.'s mens rea analysis. Section 139 of the Criminal Code was amended in 1986 to include a due diligence defence to a charge under 146 (now s. 153). Section $139(5)$ reads:

It is not a defence to a charge under section $146,154,166,167$ or 168 or subsection (2) or (4) that the accused believed that the complainant was eighteen years of age or more at the time the offence is alleged to have been committed unless the accused took all reasonable steps to ascertain the age of the complainant.

32. $R$ v. Brooks (1989), 93 A.R. 1. (C.A.).

33. This paper will not address the issue of when the removal of mens rea for circumstances can be justified as a reasonable limit under s. 1 of the Charter. See $R$ v. Nguyen (1989), 57 Man. R. (2d) 267 (C.A.) and $R$ v. Ferguson (1987), 16 B.C.L.R. (2d) 273 (C.A.).

34. For example, how would the Alberta Court of Appeal explain the British Columbia Court of Appeal's decision in Brooks, supra, note 16 that the offence of assault causing bodily harm does not require mens rea for the causing of bodily harm? Surely the causing of bodily harm is an essential element of the offence. 


\section{B. THE IMPLICATIONS OF VAILLANCOURT FOR THE CRIME OF MURDER}

I would now like to examine the effect of Vaillancourt on the remaining murder provisions in the Criminal Code, including the rest of s. 213, parties to murder under a combination of s. 21(2) and s. 212, and the first degree murder provisions in s. 214. Because murder is a unique offence, the courts have required a strict correspondence between the consequence of death and some mens rea for that consequence. Thus, in evaluating the requirements for a murder conviction, the courts are strictly scrutinizing any attempts by Parliament to weaken the correspondence between consequences and mens rea. However, the sentencing context, i.e. in the classification of murder as first or second degree, the courts have shown a lower level of scrutiny and the consequence/circumstance distinction discussed above is a useful tool for describing what the courts have done in this area.

\section{Section 213(a)-(c)}

Unless the Supreme Court of Canada decides to retreat from Vaillancourt altogether, it is likely that the rest of s. 213 will be struck down by the Court. ${ }^{35}$ In Vaillancourt, Lamer J., indicated that all of s. 213 violates ss. 7 and 11(d) of the Charter. He went on to find that s. 213(d) could not be saved as a reasonable limit under $\mathrm{s}$. 1, but he did not consider whether the rest of s. 213 could be upheld as a reasonable limit under s. 1. It is less obvious that the other subsections of 213 violate s. 7 since subsections (a)-(c) all require some level of mens rea with regard to causing harm. Lamer J. has relieved future accused from having to establish such a violation. At the $s .1$ stage, one might think that the Crown would have a heavier burden in justifying subsections (a)-(c) since the compelling objective of deterring crimes with weapons does not apply to these subsections. All things considered, the future of s. 213 does not look promising.

\section{(a) Section 213(a)}

There appears to be a consensus that s. 213(a) is invalid since it requires only the intent to cause bodily harm during the commission of one of the underlying offences and does not require mens rea (objective or subjective) with respect to

35. Section 213(a)-(c) provide that an individual who causes the death of a person while committing or attempting to commit one of the enumerated offences is guilty of murder if

(a) he means to cause bodily harm for the purpose of

(i) facilitating the commission of the offence, or

(ii) facilitating his flight after committing or attempting to commit the offence and the death ensues from bodily harm;

(b) he administers a stupefying or overpowering thing for a purpose mentioned in paragraph a, and the death ensues therefrom;

(c) he wilfully stops, by any means, the breath of a human being for a purpose mentioned in paragraph $a$, and the death ensues therefrom

Most academic commentators writing after Vaillancourt have assumed that all of s. 213 violates s. 7 of the Charter. See Isabel Grant, " $R$ v. Vaillancourt: The Constitutionalization of Mens Rea", supra, note 2; S.J. Usprich, Isabel Grant and Allan Manson, "Vaillancourt: A Criminal Reports Forum", (1987) 60 C.R. (3d) 332; Ross McNab, "Case Comments: $R$ v. Vaillancourt”, supra, note 2; Peter MacKinnon, "Case Comment: Vaillancourt v. The Queen", supra, note 2. 
causing death. The Courts of Appeal in Ontario, Alberta, Manitoba and British Columbia have all invalidated s. 213(a). New Brunswick is the only provincial Court of Appeal to hold s. 213(a) valid.

In $R$ v. Giff,,$^{36} R$ v. McDonald,,$^{37}$ and $R$ v. Sit ${ }^{38}$ the Ontario Court of Appeal held that s. 213(a) violates s. 7 of the Charter since it enables the Crown to convict of murder persons who neither foresaw nor could reasonably have foreseen death as the result of their intentional infliction of bodily harm. The Court applied Lamer J.'s analysis of $s .1$ in Vaillancourt and found that s. 213(a) could not be upheld as a reasonable limit because the subsection is not necessary to deter the intentional infliction of bodily harm during the commission of a crime; the life sentence available for manslaughter is a sufficient deterrent..$^{39}$

The Alberta Court of Appeal has also held that s. 213(a) violates the Charter. In $R$ v. Martineau, ${ }^{40}$ the Court followed Giff and held that since subs. (a) required no objective foresight of death, it must be a violation of ss. 7 and 11(d) of the Charter. For the same reasons given in Vaillancourt, the Court held that s. 213(a) could not be sustained under s. 1. The Manitoba Court of Appeal also struck down s. 213(a) in $R$ v. J.T.J. (No. 2). ${ }^{41}$

The British Columbia Court of Appeal passed up its first opportunity to find s. 213(a) invalid. In $R$ v. Arkell,,$^{42}$ the appellant argued that a conviction for first degree murder based on the combination of s. 213(a) and s. 214(5) violated his ss. 7 and 11(d) Charter rights. McLachlin J.A. (as she was then) stated:43

In my view, that argument cannot be made, given counsel's admission that he is not seeking to challenge the constitutional validity of s.213(a). The question of the validity of $s .214(5)$ is the only issue before us and must be approached on the assumption that the accused was validly convicted of murder under s. 213.

Mr. Arkell's appeal was thus dismissed. However, just five months later in $R \mathbf{v}$. Rodney, the British Columbia Court of Appeal held: ${ }^{44}$

We are all of the view that the majority judgment of the Supreme Court of Canada in $R v$. Vaillancourt (1987) 60 C.R. (3d) 289, which struck down Code s. 213(d) on constitutional grounds requires us to apply the same reasoning and reach the same conclusion with respect to Code s. $213(\mathrm{a})$ :

Despite the general consensus that s. 213(a) is invalid, the New Brunswick Court of Appeal has implied that the section is constitutional. In $R$ v. Legere, ${ }^{45}$ the Court

36. $R$ v. Giff (1988), 64 C.R. (3d) 328 (Ont. C.A.).

37. $R$ v. McDonald, (1988) 28 O.A.C. 347.

38. $R$ v. Sit (1989), 31 O.A.C. 21 (application for leave to appeal to Supreme Court of Canada granted, June 29, 1989).

39. The maximum punishment for manslaughter is life imprisonment. See s. 219 (now 236) of the Criminal Code.

40. $R$ v. Martineau (1988), 43 C.C.C. (3d) 417 (Alta. C.A.) (application for leave to appeal to the Supreme Court of Canada granted, June 8,1989$)$.

41. R v. J.T.J. (No. 2) (1988) 40 C.C.C. (3d) 97 (Man. C.A.).

42. Rv. Arkell (1988), 64 C.R. (3d) 340 (B.C.C.A.) (application for leave to appeal to the Supreme Court of Canada granted, February 2, 1989).

43. Ibid., at 349.

44. Rv. Rodney (Oral Reasons for Judgment given Nov. 1, 1988, B.C.C.A., CA 002590) at p. 2 (application for leave to appeal to the Supreme Court of Canada granted, June 8, 1989).

45. $R$ v. Legere (1988), 43 C.C.C. (3d) 502 (N.B.C.A.) (application for leave to appeal to the Supreme Court of Canada dismissed Oct. 12, 1989). Leave to appeal was denied in Legere, apparently because Legere had escaped from custody. 
was faced with an appeal by an accused convicted of second degree murder. It was not clear under what section of the Code the accused had been convicted because the jury was charged under combinations of s. 21 and s. 212, 213(a) and (d). The Court of Appeal concluded that if the conviction had been based upon s. 213(d), a new trial was required since s. 213(d) had been invalidated in Vaillancourt. However, because the evidence as to the use of a weapon was so weak, the Court concluded that the accused must have been convicted under s. 213(a) in combination with s. 21. The Court upheld the accused's conviction and did not even refer to the possible constitutional problem with s. 213(a).

The Supreme Court of Canada has granted leave to appeal in Rodney, Martineau, Sit (all of which found s. 213(a) invalid) and in Arkell. Thus the validity of s. 213(a) should finally be determined in the near future.

\section{(b) Section 213(b)}

Section 213(b) deals with deaths that result from the administration of a "stupefying or overpowering thing" to facilitate the commission of or escape from one of the enumerated offences. There are no post-Vaillancourt decisions addressing s. 213(b) and this subsection is rarely invoked by the Crown. It is likely that deaths resulting from such circumstances could be subsumed under s. 213(a) which requires only the intent to cause bodily harm.

\section{(c) Section 213(c)}

Provincial appellate courts seem less certain about the invalidity of s. 213(c) than they are about s. 213(a). Section 213(c) provides that an accused is guilty of murder where during the commission of one of the underlying offences (or an attempt thereof) he or she "wilfully stops, by any means, the breath of a human being" for the purpose of facilitating the commission of or flight from the offence. The uncertainty is generated by the fact that the provision requires that an accused wilfully stop the breath of another person and it is at least arguable that someone who wilfully stops the breath of another ought to foresee the risk of death to that individual. However, Lamer J. indicated in Vaillancourt (without reference to this concern) that this subsection was also contrary to s. 7 .

The Ontario Court of Appeal has considered s. 213(c) in two recent decisions, although in neither case was it essential for the decision. In $R$ v. McDonald the Court found it unnecessary to pass on the validity of s. 213(c). The Court indicated: ${ }^{46}$

. . . it is unnecessary to determine whether s. 213 (c) can be held to be constitutional by invoking

s. 1 of the Charter. For our purposes, without deciding the matter, we are prepared to assume that it is also constitutionally invalid.

Just six months later in $R$ v. Sit, the Ontario Court of Appeal proceeded on the basis that s. 213(c) was constitutionally valid. The Crown had argued that anyone who wilfully stops the breath of an individual must have objective foreseeability of death and that the section therefore satisfies the Vaillancourt test. Mr. Justice Cory in dissent also proceeded on the basis that s. 213(c) was valid, but pointed out that Lamer J. in Vaillancourt had stated that ss. 213(a)-(d) were all prima facie 
violations of s. 7 and 11(d). Cory J.A. (as he was then) also noted that, when s. 213(c) was coupled with s. 21(2), the objective foreseeability of death requirement might not be satisfied.

In Legere, the New Brunswick Court of Appeal criticized the Crown for not relying on s. 213(c) when there was clear evidence of a strangulation during the course of a robbery. Thus the Court implied that a conviction under s. 213(c) would have been valid. This case was decided just a week after the Ontario Court of Appeal indicated in McDonald that the section was invalid.

Since the validity of s. 213(c) remains in doubt, it is unlikely that Crown prosecutors will rely on this section until the issue has been clarified by the Supreme Court of Canada. However, none of the cases in which leave has been granted by the Supreme Court of Canada deal directly with s. 213(c) and thus the Court may decide not to pass judgment on the validity of the subsection.

\section{(d) Impact of Finding Section 213 Invalid}

The invalidation of s. 213 may not have a great impact on the Crown's ability to secure a murder conviction because, in most cases, a murder conviction can be obtained under s. 212(a) or under s. 212(c). There may be a few cases where the Crown will not be able to meet the objective foreseeability of death requirement in s. 212(c) and in these cases the proper verdict will be manslaughter. A conviction for manslaughter allows the sentencing judge to consider individual circumstances in determining the appropriate sentence. An accused who could once have been convicted of murder under s. 213 may also be tried for the underlying offence in $\mathrm{s.} 213 .^{47}$

The invalidiation of s. 213(d), and probably the rest of s. 213, will not necessarily result in serious criminals receiving sentences more lenient than they deserve. For example, the Alberta Court of Appeal has recently considered the appropriate sentence for several co-accused who were originally convicted of murder under s. 213(d) and who, as a result of Vaillancourt, later had verdicts of manslaughter substituted for the murder convictions. In $R$ v. Tallman ${ }^{48}$ the Alberta Court of Appeal indicated that manslaughter convictions arising out of circumstances which would once have resulted in s. 213 convictions are to be treated seriously and to be given severe sentences. In this particular case, the murder was clearly unintended, and yet the Court said that the proper sentence, had the accused been adults, would have been fifteen years. ${ }^{49}$

The experience of courts dealing with individuals convicted under s. 213(d) before the Vaillancourt decision also supports the conclusion that the invalidation

47. Section 518 (now s. 589) of the Criminal Code provides that an indictment charging an accused with murder cannot charge any other offence. The Department of Justice is considering the amendment of this section. The primary proposal of the government is to allow the joinder of indictable offences arising "out of the same transaction" as the murder charge. If this amendment were made, an accused who would once have been charged with murder under s. 213, could be charged with murder under s. 212 in addition to a charge for the underlying offence that would have triggered s. 213. Thus, for example, an accused who kills during a robbery could be tried for murder/manslaughter and robbery.

48. R v. Tallman (1989), 94 A.R. 251 (C.A.).

49. In fact, the actual sentences imposed were much less because of the age of the accused, their impoverished backgrounds and the amount of time spent in pre-trial custody. 
of s. 213 will not unduly impair the Crown's ability to secure murder convictions. There have been several cases where convictions were obtained under s. 213 prior to Vaillancourt with their appeals heard after Vaillancourt was decided. ${ }^{50}$ Section 613(1)(b)(iii) of the Criminal Code has been used to deny relief in cases where the appellate court is of the view that a conviction under some other murder provision would have been inevitable. ${ }^{51}$

In most of the cases where s. 613(1)(b)(iii) has been successfully argued by the Crown, the appellate court has proceeded on the basis that the evidence of intent to cause grievous bodily harm or death was so strong that no reasonable jury properly instructed could have found that there was no intent under s. 212(a). Both the Ontario Court of Appeal and the British Columbia Court of Appeal have been willing to say that a conviction could have been obtained under s. 212(a) even if the jury was never charged under that section..$^{52}$

Courts seem more reluctant to apply s. 613(1)(b)(iii) where s. 21(2) was involved and the individual was convicted as a party to murder. ${ }^{53} \mathrm{In} R \mathrm{v}$. Martineau ${ }^{54}$ for example, the jury was charged under the combination of s. 21(2) with s. 213(a) or (d). Because the accused, whose intentions were unclear, was only a party to the murder, and because the jury was not instructed on any subsection of $s .212$, the

50. The curative provision in 613(1)(b)(iii) enables an appeal court to dismiss an accused's appeal from an accused even though the trial judge made an error of law if "no substantial wrong or miscarriage of justice has occurred."

The Supreme Court of Canada's decision in R v. Wigman, [1987] 1 S.C.R. 246, 4 W.W.R. 1 is authority for applying the decision in Vaillancourt to cases still in the system at the time the Supreme Court of Canada's decision was handed down. In Wigman, the Supreme Court of Canada held that when the Court overruled itself as to the proper interpretation of a statutory provision, all those still in the system, i.e. those who had not exhausted their appeals, were entitled to the benefit of the new rule. Individuals whose convictions were final would be precluded from relitigating their cases. While Wigman involved the interpretation of a statute, the Court noted that the same reasoning would apply in the case of constitutional invalidity.

51. It is interesting to note that none of the cases applying s. 613(1)(b)(iii) even mention s. 24(1) of the Charter. In denying relief to the appellant, courts assume without analysis that a Criminal Code provision can be used to deny a remedy for a constitutional violation.

52. $R$ v. Giff, supra, note 36 , for example, involved the sexual assault and murder of a sixteen year-old girl. The victim was assaulted, stabbed and left in the snow to die. The accused did not testify but told police that he had killed the victim to silence her because she had threatened to tell the police about the assault. The jury in Giff was charged only on the basis of s. 213(a); s. 212 was not put to the jury. The accused had admitted the killing and the only real issue was whether the murder was first or second degree under s. 214(5), i.e. whether the killing had taken place during or after the sexual assault. The Ontario Court of Appeal held that even though the jury had not addressed the issue of intent under s. 212(a), and even though appeal courts should not decide questions of fact not put to the jury, s. 613(1)(b)(iii) could nonetheless be invoked because:

... no reasonable jury could come to any conclusion other than that the appellant intended to cause bodily harm to the victim which he knew was likely to cause death and was utterly indifferent to whether or not death ensued. (at 340)

See also $R$ v. McDonald, supra, note 37, and $R$ v. James (June 2, 1989, B.C.C.A. No. V100754) in which convictions were upheld even though no constitutional definition of murder had been left with the jury.

53. $R$ v. Harry (1987), 24 O.A.C. 213; $R$ v. Martineau, supra, note 40; $R$ v. Logan, Logan and Johnson (1988), 30 O.A.C. 321 (application for leave to appeal to the Supreme Court of Canada granted August 10, 1989); $R$ v. Pham (1989), 32 O.A.C. 14; $R$ v. Kasachev, (March 10, 1989, B.C.C.A., No. v00213, unreported); $R$ v. Harris (1989), 32 O.A.C. 131 (application for leave to appeal to the Supreme Court of Canada dismissed Oct. 12, 1989).

54. Supra, note 40 . 
Alberta Court of Appeal refused to apply the saving proviso. The one instance where an appellate court applied the saving proviso to uphold a conviction for a party was a case in which the underlying offence was orchestrated by the party and his involvement in the killing was substantial. ${ }^{55}$ The majority of the Ontario Court of Appeal was clearly influenced by the horrendous fact situation and the degree of planning by the accused. ${ }^{56}$

In conclusion, it seems likely that the rest of s. 213 will be invalidated. However, this does not inevitably mean that the Crown will be unable to secure murder convictions for individuals who kill while committing other serious offences nor that such accused will be treated too leniently by the law. The courts' use of s. 613(1)(b)(iii) to uphold convictions obtained under s. 213 of the Criminal Code should allay the fears of those who were worried that Vaillancourt would make it difficult for the Crown to sustain existing convictions obtained under s. 213(d).

One of the most telling criticisms of s. 213(d) was that it was unnecessary. In almost every case an accused could have been convicted of murder under some other section and, in those few cases where this was not so, a manslaughter conviction would have been sufficient to do justice. Section 213 should not be sorely missed because it was never greatly needed.

\section{Parties to Murder}

The decision in Vaillancourt has also had implications for the law dealing with parties to murder. The accused in Vaillancourt argued before the Supreme Court of Canada that s. 7 of the Charter requires a subjective mens rea for every element of a crime, including any relevant consequences. Thus, before an accused could be convicted of murder, the Crown would have to show that he or she had an actual awareness of at least a likelihood that his or her actions would cause death.

Had the Court accepted this broad view, offences such as manslaughter and causing death by criminal negligence would have been brought into question, and the common intention parties provision in s. 21(2) would have fallen in its entirety because it involves an objective standard of liability. Thus, it is not surprising that the Court adopted a narrower view and refrained from passing judgment on the validity of s. 21(2) of the Criminal Code. Section 21(2) provides

Where two or more persons form an intention in common to carry out an unlawful purpose and to assist each other therein and any one of them in carrying out the common purpose, commits an offence, each of them who knew or ought to have known that the commission of the offence would be a probable consequence of carrying out the common purpose is a party to that offence. (emphasis added)

55. $R$ v. Sit, supra, note 38 .

56. Finlayson J.A. summed up as follows:

The facts in the case on appeal are very bad. I am of the opinion that no substantial wrong or miscarriage of justice has occurred in the conviction of the appellant. It can readily be justified by the application of s. 21(1) [aiding and abetting] to s. 229(a) [s. 212(a)] and, if necessary, by the application of s. 21(2), as modified by Logan, to s. 230(c) [s. 213(c)]. . . . I do not find it useful to speculate as to what was going on in the minds of the members of the jury based on questions asked of the trial judge. The facts speak for themselves in the case on appeal (at 39).

Mr. Justice Cory dissented on the s. 613(1)(b)(iii) issue. 
The words "ought to have known" result in an objective standard of liability for a party to an offence under s. 21(2).

Section 21(2) can be conceptualized as imposing liability for the unintended consequences of criminal action. Liability is premised on the mens rea for the underlying common purpose of the parties. Once the Crown has proved this underlying fault, s. 21(2) holds the individual responsible for all the foreseeable consequences of engaging in the unlawful purpose. All parties to the underlying common purpose are treated as one and are held jointly responsible for the consequences of all of their actions unless those consequences were unforeseeable. Parties must bear the risk of further harm being caused as a result of their unlawful purpose. It is important to note that the law does not judge all parties on an objective standard; only those who enter into a common purpose with the principal offender. ${ }^{57}$

Although Lamer J. expressly stated in Vaillancourt that he did not want to address the validity of s. 21(2), he has inferentially passed judgment on the validity of s. 21(2) at least in cases where it is being applied in combination with any of the Code's murder provisions. If a murder conviction can only be based on subjective foresight, no one can be convicted of murder on the basis of the combination of the objective test in s. 21(2) and any murder provision.

There have been two interesting cases in the Ontario Court of Appeal challenging the combination of s. 21(2) with other homicide provisions. In $R$ v. Logan, Logan and Johnson, ${ }^{58}$ the Ontario Court of Appeal held that, since the Supreme Court of Canada in $R$ v. Ancio 59 had held that a conviction for attempted murder requires a specific intent to kill, it would violate the principles of fundamental justice to allow a party to attempted murder (under s. $21(2)$ ) to be convicted on a lesser (i.e., objective) standard of mens rea than the principal. The Court stated: ${ }^{60}$

In our opinion, insofar as s. 21(2) permits a conviction of a party for the offence of attempted murder on the basis of objective foreseeability, a lesser degree of mens rea than is required for the principal, it is contrary to the principle of fundamental justice. Nor do we think that this departure from the principle of fundamental justice can be saved by $s$. 1 of the Charter.

The Court went on to conclude that the words "ought to have known"' in s. 21(2) are inoperative in the context of attempted murder and that the liability of a party to attempted murder must be based on a subjective standard of mens rea.

The Ontario Court of Appeal took this finding one step further and applied Logan to the context of murder under s. 212(a) in $R$ v. Harris. ${ }^{61}$ In Harris the accused was convicted of second degree murder on the basis of s. 21(2) in combination with either s. 213(d) or s. 212(a). Since s. 213(d) had been invalidated in Vaillancourt, the Court had to consider whether the accused could have been convicted under the combination of s. 212(a) and s. 21(2). If the accused had been convicted under this combination, his conviction would have been based on an objective standard of mens rea.

57. Parties to murder under s. 2l(1)(b) and (c) [the aiding and abetting provisions] are judged on a subjective standard of mens rea.

58. $R$ v: Logan, Logan and Johnson, supra, note 53.

59. $R$ v. Ancio (1984), 10 C.C.C. (3d) 385, [1984] 1 S.C.R. 225, 6 D.L.R. (4th) 577.

60. $R$ v. Logan, supra, note 53 at 355 .

61. $R$ v. Harris, supra, note 53. 
The Court extended Logan and held that it violated s. 7 of the Charter to allow an objective standard of mens rea for a party to murder while requiring a stricter subjective standard for the actual perpetrator of the offence. The Court thus read down s. 21(2) to eliminate the objective test. ${ }^{62}$
On the charge of murder as defined in s. 212(a)(i) or (ii), where s. 21(2) is invoked to determine the liability of a party to the murder, I would, following Logan, hold that the words "ought to have known" in that section are inoperative and that these words should be ignored in determining the guilt of the party to the offence of murder.

There are two possible interpretations of the Court of Appeal judgment in Harris both of which have some support in the judgment. First, Harris could be interpreted as following Lamer J.'s dicta in Vaillancourt that all murder convictions require subjective mens rea. This passage of the Lamer judgment is quoted in Harris, but the Court does not state expressly that this is the rationale of its decision. If this interpretation is correct, then s. 212(c) would be invalid and s. 21(2) could not apply to any murder charge. This first interpretation would enable courts to limit Harris to the crime of murder ${ }^{63}$ Secondly, the case could be read as applying some sort of equality test - it is unfair to hold a party to a stricter standard than the more blameworthy principal offender. This seems to be more closely tied to the Logan decision. The Court stated in Harris: ${ }^{64}$

Central to the decision of this court in Logan is the finding that it is contrary to the principles of fundamental justice, guaranteed by s. 7 of the Charter, to impose liability for attempted murder on an accessory on the basis of objective foresight, that is the foresight of an ordinary person, but require proof of subjective intent to cause death on the part of the actual perpetrator.

and later ${ }^{65}$

Although Logan was a case of attempted murder, I am unable to distinguish it in principle from the present case of murder. Murder, based on s. 212(a)(i) or (ii), no less than attempted murder must be based on the subjective foresight of the perpetrator, and a party should not be convicted of murder on the basis of the combination of the objective foresight required by s. 21(2) of the Criminal Code and the s. 212 murder provisions.

The suggestion that it is unfair to punish a party on a lesser standard than that of a principal offender applies to all criminal offences, not just to the crime of murder. Thus, if this second interpretation is correct, the decision could land a death blow for s. 21(2) in combination with any substantive Code offence which requires subjective mens rea for the conviction of the principal offender.

Section 21(2) provides that the party is guilty of the same offence as the principal offender. In most crimes, the sentencing judge can take into account the degree of involvement of a party and the degree of foresight actually held by the individual to determine an appropriate sentence. Where a party under s. 21(2) had no subjective foresight, it is likely that the principal offender will receive a harsher sentence than the party. In murder, however, because there are mandatory minimum sentences, the trial judge does not have sufficient discretion to tailor the sentence to the precise

62. Ibid., at 141.

63. It should be noted that in $R$ v. Harris, Ibid., the Court did not mention s. 212(c) (now s. 229(c)) which incorporates an objective standard of mens rea for a death caused during the commission of an offence. I have been unable to find any cases challenging s. 212(c). The validity of s. 212(c) will depend on the extent to which the rest of the Supreme Court of Canada adopts Lamer J.'s dicta in Vaillancourt, supra, note 1, that murder, because of its special stigma, requires subjective mens rea for the consequence of death.

64. $R$ v. Harris, supra, note 53 at 140 .

65. Bid. 
circumstances of the party. The minimum life sentence with a ten-year parole ineligibility period may be unjust if the party's involvement was limited and there was no actual foresight of death. While the inequality between party and principal can be addressed in the sentencing process for most offences, such is not the case with murder. Thus there is some justification for reading down s. 21(2) in the context of murder so that a party can only be convicted if he or she had actual foresight of death. Those accused who ought to have foreseen death, but in fact did not, could still be convicted of manslaughter. ${ }^{66}$

Before we can fully understand the importance of Logan and Harris, the Supreme Court of Canada will have to consider whether it is consistent with the principles of fundamental justice to punish a party on a lower standard of mens rea than a principal offender. Leave to appeal to the Supreme Court of Canada has been granted in Logan but denied in Harris. If the Court does not address the general validity of s. 21(2) in Logan, the issue will likely come before them again. Harris has opened the door for a party convicted under the combination of s. 21(2), and any other substantive provision which requires subjective mens rea for the principal offender, to challenge the conviction under $\mathbf{s} 7$ of the Charter.

\section{First-Degree Murder}

Vaillancourt has also had an impact on the classification of murder into first or second degree. Section 214 of the Criminal Code sets out which murders are to be classified as first degree. This section does not create a substantive offence of first degree murder but is rather a classification provision for sentencing purposes ${ }^{67}$ If an accused is convicted of murder under s. 212 or s. 213 , the jury must look at the factors in s. 214 in determining whether to classify the murder as first or second degree.

In Vaillancourt, Lamer J. indicated that murder is the most serious crime in our society because of the special stigma associated with it. In practical terms, the mandatory minimum sentencing provisions make murder unique. Anyone convicted of murder is subject to a mandatory life sentence. An accused convicted of first degree murder will serve a minimum of twenty-five years before being eligible

66. The suggestion that s. 21(2) could be read down in the context of murder is not the same as suggesting the kind of constitutional exemption described by the Ontario Court of Appeal in Re Seaboyer and Gayme and the Queen (1987), 37 C.C.C. (3d) 53. In that case, the Court refused to strike down the rape shield laws in the Criminal Code but indicated that the provisions might violate the rights of an accused in certain cases, depending on the facts of the case. Thus the Court held that an accused person could seek a constitutional exemption where the application of the provisions in the particular case would be in violation of the Charter.

In the Seaboyer type of constitutional exemption, the burden would be on the accused in each case to show why the provision is unfair when applied to him or her. This puts courts in the awkward position of evaluating the constitutional validity of a provision on a case by case basis. If the Supreme Court of Canada were to read down s. 21(2), thus making it inapplicable in the context of murder, there would be no onus on an accused charged with murder to show that the provision should not apply, nor would there be inconsistent results reached in different cases.

67. $R$ v. Farrant, [1983] I S.C.R. 124, (1983) 4 C.C.C. (3d) 354. 
for parole ${ }^{68}$ whereas an accused convicted of second degree murder may be eligible for parole after as little as ten years. ${ }^{69}$

Section 214(2) provides that murder is first degree when it is planned and deliberate. Under s. 214(2) it is a further mental state of the accused which justifies the increased punishment. This section raises little controversy since most people agree that a murder which is calculated and planned in advance is more blameworthy than one which is not. However, not all the provisions in s. 214 are premised on the accused's state of mind. Section 214(4) classifies murder as first degree on the basis of the identity of the victim. Section 214(5) elevates murders to first degree if they take place in the context of certain other serious offences. Both these provisions suggest that factors other than mens rea may justify increased punishment. The focus on factors other than mens rea has led to constitutional challenges to both these provisions; challenges grounded in the Vaillancourt decision.

\section{(a) Section 214(4)(a)}

Section 214(4)(a) provides that, whether or not a murder is premeditated, it will be first degree murder if the victim is

. . . a police officer, police constable, constable, sheriff, deputy sheriff, sheriff's officer or other person employed for the preservation and maintenance of the public peace, acting in the course of his duties.

Prior to Vaillancourt, the courts had split as to whether the Crown had to prove that the accused knew the victim was a police officer acting in the course of his or her duties before being subject to this section. The Ontario Court of Appeal had suggested in its pre-Charter decision of $M$ unro $^{70}$ that s. 214(4)(a) did not require any mens rea with regard to the status of the victim and thus that an accused could be convicted of first degree murder under s. 214(4)(a) even if he or she did not know the status of the victim. ${ }^{11}$

In $R$ v. Collins ${ }^{72}$ the accused challenged his conviction for first degree murder on the basis that s. 214(4)(a) violated s. 7 of the Charter. The accused argued that the stigma associated with first degree murder (and the harsh penalty) can only be justified if the Crown has proven an increased level of moral blameworthiness, i.e. mens rea, that is not present in second degree murder. The accused argued that the added blameworthiness of first degree murder should be found in planning and deliberation, and that s. 214(4)(a) is invalid because it does not require any premeditation.

68. Criminal Code R.S.C. 1970, c. C-34 s. 642 (now s. 745 under R.S.C. 1985, c. C-46). The distinction between degrees of murder originated in the time when some murders were punishable by death (capital murders) and some were not (non-capital murders). When the death penalty was abolished in 1976, s. 669 , making some murders punishable by a minimum twenty-five years before parole eligibility, was seen as a concession to those who wanted to retain the death penalty.

69. Section 669 (a.1) of the Criminal Code R.S.C. 1970 (now s. 742(a.1)) provides a minimum life sentence for second degree murder but gives the trial judge the discretion to set the minimum period before parole eligibility at between ten and twenty-five years.

70. R v. Munro and Munro (1983), 8 C.C.C. (3d) 260, 36 C.R. (3d) 193 (Ont. C.A.).

71. In $R$ v. Shand (1971) 3 C.C.C. (2d) 8 [1971] 3 W.W.R. 573, (Man. C.A.) it was held that S، 214(4)(a) (the former 202A(2)) required the Crown to prove that the accused knew that the person killed was a police officer employed for the preservation and maintenance of the public peace.

72. $R$ v. Collins (1989), 32 O.A.C. 296, 48 C.C.C. (3d) 343. [hereinafter Collins cited to O.A.C.]. 
In Collins, the Ontario Court of Appeal retreated from its pre-Charter position and interpreted this section as requiring proof that the accused knew the status of the victim. Such an interpretation would provide the increased moral blameworthiness necessary for first degree murder and would thus justify the harsh penalty. Goodman J.A. stated: ${ }^{73}$

I am of the view, however, that under s. 214(4)(a) there is an onus on the Crown to establish beyond a reasonable doubt that the victim was a person who falls within the designation of the occupations set forth in that subsection acting in the course of his duties to the knowledge of the accused or with recklessness on his part as to whether the victim was such a person so acting.

It is my view that s. 214(4)(a) should be interpreted in such a manner that requires proof of the facts which give rise to the added moral culpability or which would act as an additional deterrent. It is clear to me that to fulfill such interpretation, it is necessary that the Crown prove that the murderer had knowledge of the identity of the victim as one of the persons designated in the subsection and that such person was acting in the course of his duties or was reckless as to such identity and acts of the victim.

The Court conceded that if s. 214(4)(a) were interpreted such that the Crown did not have to prove that the accused knew the victim's status, then the subsection would violate s. 7 of the Charter. The following example was presented: ${ }^{74}$

If, for example, a gunman sees two persons on the street dressed in plain clothes of whom one is a merchant walking home and the other is a detective on his way to investigate or in the process of investigating a break-in and if the gunman decides without planning and deliberation to shoot and kill one of them and does so, he would be guilty of murder no matter which person he killed. In the case of the killing of the ordinary citizen he would be guilty of second degree murder with a sentence of life imprisonment with a possibility of parole eligibility after ten years, but in the case of the killing of the detective, he would be guilty of first degree murder with a sentence of life imprisonment with a possibility of parole in no less than twenty-five years. . . .

Although the crime of murder is deserving of the heavy sentence involved, it seems to me that there would be no difference in moral culpability in the example set forth above no matter which person was the victim nor would there be any additional deterrent provided under s. 214(4)(a) in those circumstances if proof of knowledge that the detective was indeed a detective acting in the course of his duty were not required. There would then be no rational or logical reason for imposing a heavier penalty in the case where the murderer killed the person who he did not know and had no reason to know was a police officer acting in the course of his duties.

On the other hand, if s. 214(4)(a) is interpreted to require proof of such knowledge before the murder can be classified as first degree murder, then a heavier sentence can be justified on the basis of added moral culpability or as additional deterrent on the grounds of public policy. In such event, it is my opinion that the subsection would not contravene the provisions of $s .7$ of the Charter.

This interpretation of s. 214(4)(a) is consistent with the courts' general approach to mens rea for circumstances discussed above. The Ontario Court of Appeal in Collins held that in order to justify the increased sentence and stigma that go with a conviction for first degree murder, the Crown must prove that the accused actually knew the status of the victim. Knowledge of the circumstance that makes the murder especially blameworthy is required by s. 7 of the Charter.

Given that the difference between the sentence for first degree and second degree murder may be as great as fifteen years, it is appropriate to extend the mens rea analysis to a sentencing provision and require some level of moral

73. Ibid., at 317.

74. Ibid., at 317-318. 
blameworthiness accompanying the circumstance that makes the murder particularly heinous. ${ }^{75}$

\section{(b) Section 214(5)}

One of the most serious problems associated with s. 213 constructive murders was the combination of that section with the first degree murder provisions in s. 214(5). Section 214(5) provides that all murders that are committed during the course of certain enumerated offences are first degree murders and thus subject to the mandatory minimum of twenty-five years imprisonment before parole eligibility. Section 214(5) includes within it many but not all of the enumerated offences in s. $213 .{ }^{76}$ Section 214(5) has been used by the Crown to elevate some constructive s. 213 murders into first degree murder depending upon the underlying offence. It is irrelevant whether or not the s. 213 murder was intentional or accidental; once the Crown proves that the death was caused during the commission of one of the underlying offences in s. 214(5), the murder will be classified as first degree.

The reasoning in Vaillancourt has been used to challenge the validity of s. 214(5). In $R$ v. Arkell, the accused argued that since s. 214(5) is not based on moral blameworthiness, or mens rea, it violates the principles of fundamental justice. He also argued that the distinction between first and second degree murder in s. 214(5) is arbitrary and irrational, and hence in violation of s. 7 and s. 11(d) of the Charter.

Madam Justice McLachlin, for a unanimous British Columbia Court of Appeal, held that s. 214(5) only classifies murders as first degree or second degree and does not create a substantive offence. She held that Vaillancourt deals only with the mens rea requirement of substantive offences, not sentencing classifications. In addition, s. 214(5) is premised on the existence of a valid conviction for murder, with

75. The classification provision in $214(4)$ (a) withstood a constitutional challenge on the basis of section 7, 9, 12 and 15 of the Charter in R v. Bowen and Kay (1988), 63 Alta. L.R. (2d) 311. The Court decided that even though s. 214(2) provides that a "planned and deliberate" murder is first degree and s. 214(4)(a) provides that the "impulsive" killing of a police officer on duty is also first degree, it is not cruel and unusual punishment within the meaning of s. 12 of the Charter to impose the same mandatory life sentence without parole eligibility for twenty-five years for both types of murder. The Court held that the effect of the punishment is not grossly disproportionate to the crime committed since numerous factors are considered by Parliament in determining a sentence for various types of murders which are all classified as first degree. The challenges to s. 214(4)(a) on the basis of ss. 7, 9, and 15 were also rejected by the Court.

The Law Reform Commission of Canada would retain a provision similar to s. 214(4)(a) but the focus would shift from the identity of the victim to the purpose of the activity in which the accused was engaged when he or she committed the offence. Section 6(4)(c) of the proposed new Code would make a murder first degree if it were committed "for the purpose of preparing, facilitating or concealing a crime or furthering an offender's escape from detection, arrest or conviction." This provision would cover almost all killings of police officers and prison guards but would also cover the killing of any other person in these circumstances. Law Reform Commission of Canada, Recodifying Criminal Law: Report 31 (Ottawa: L.R.C.C., 1987) at 58.

76. Several offences enumerated in s. 213 are not included in s. 214(5): sabotage, piratical acts, escape or rescue from prison or unlawful custody, assaulting a peace officer, robbery, breaking and entering, and arson. 
mens rea constituting an essential element of that conviction. Relying on the judgment of Wilson J. in $R \mathrm{v}$. Pare, ${ }^{77}$ Madam Justice McLachlin stated: ${ }^{78}$

\begin{abstract}
. . . it must be recognized that many factors other than the accused's degree or (sic) moral blameworthiness must be considered by Parliament in establishing a sentencing scheme. General deterrence, the degree of perceived danger to the public and the prevalence of certain types of offences are only some of the other considerations which Parliament may properly consider. It follows that the mere fact that a harsher sentence may be imposed for one offence than for another offence which is arguably more blameworthy does not mean that the scheme that permits the sentence violates s. 7 of the Charter.
\end{abstract}

Madam Justice McLachlin reasoned that s. 214(5) does not exclude mens rea because the section only applies once the Crown has proven that the accused has committed a murder, and that underlying murder is assumed to have required mens rea.

However, in Arkell, the accused was convicted of first degree murder on the basis of s. 213(a) and s. 214(5). Under such a combination it is possible for an accused to be convicted of first degree murder with only the intent to commit bodily harm during the commission of the underlying offence. Thus in Arkell the Crown never had to prove any level of mens rea regarding death in order to convict the accused of first degree murder. The argument of McLachlin J.A. (as she then was) would have carried more weight if the underlying murder had been based on s. 212 rather than on $\mathrm{s.} 213 .{ }^{79}$

Applying the consequence analysis to s. 214(5), one can see that the section provides that all murders that occur in the context of certain other serious offences are first degree murders. Those who engage in the serious underlying offences listed therein are especially blameworthy if a death occurs. No additional mens rea is required for the death.

Section 214(5), like s. 213, premises the increased moral blameworthiness on the nature of the activity in which the accused is engaged when the killing takes place. The essential difference between s. 214(5) and s. 213 is that the latter defines the elements required for conviction while the former sets out the sentencing criteria. While the courts are willing to scrutinize strictly the constitutionally required elements of the substantive offence, they have not been willing to apply the same level of scrutiny to this sentencing provision..$^{80}$

In Vaillancourt, Lamer J. discussed the unique "stigma" that goes with the crime of murder. It is this stigma which justifies the strict level of scrutiny being applied to $s$. 213 by the courts. It is not immediately apparent why this argument does

77. In $R$ v. Pare, [1987] 2 S.C.R. 618, (1987) 60 C.R. (3d) 346, 38 C.C.C. (3d) 97, 45 D.L.R. (4th) 546, Madam Justice Wilson indicated that the organizing principle behind s. $214(5)$ is that all the underlying offences listed involve the unlawful domination of people by other people, and thus murders occurring during the course of such offences are particularly heinous. The decision in Pare did not address the constitutional validity of s. $214(5)$ but the Court will probably address this issue in Arkell.

78. $R$ v. Arkell, supra, note 42 at 350 .

79. The Law Reform Commission's proposed new Code (Recodifying Criminal Law, supra, note 75) would retain an analogous provision: section 6(4)(3) would render murders first degree if they took place "during the course of robbery, confinement, sexual assault or interference with transport facilities consisting of aircraft and ships".

80. The courts have traditionally been less rigorous in scrutinizing the procedures at the sentencing stage of a trial than at the conviction stage. See, for example, Wilband v. The Queen, [1967] S.C.R. 14 which classifies the dangerous offender provisions of the Criminal Code as merely part of the sentencing process. See also Isabel Grant “Dangerous Offenders” (1985) 9 Dal. Law J. 347. 
not apply to the distinction between first and second degree murder. The stigma attached to first degree murder is unique in our society. It is the stigma which once justified the death penalty and which still justifies the harshest punishment in Canadian law.

The validity of our existing first degree murder provisions is closely tied to the question of how we define the offence of murder itself. If the Supreme Court of Canada holds that an objective standard of mens rea for the crime of murder is constitutionally permissible (such as that found in s. 212(c)) then we should be concerned about the possibility of unintentional murders being elevated to first degree based on criteria other than mens rea. However, if the Court were to hold that all murders must have subjective mens rea, then applying the criteria in s. 214 to elevate a murder to first degree would be less troubling because the application of those criteria will be contingent upon a jury having found an actual intent to kill (or at least recklessness).

As a minimum, the first degree classification should be saved for intentional and perhaps reckless killings. Once that initial threshold has been passed, there is more room for Parliament to determine which intentional murders are more blameworthy than others. The intent to kill, or at least recklessness, should be the threshold requirement for first degree murder. This could be accomplished either through the definition of the substantive offence itself, or through reading this requirement into the provisions of s. 214 .

\section{CONCLUSION}

It is still too early to draw definitive conclusions about the impact of Vaillancourt. What we have seen is the courts struggling with the issue of whether mens rea is the sine qua non of moral blameworthiness in criminal law and the degree to which other factors can justify punishment.

This paper has suggested that the consequence/circumstance distinction is useful for describing the post-Vaillancourt developments for crimes against the person other than murder, but that it does not explain the cases dealing with the substantive offence of murder. Even though s. 213(d), the section struck down in Vaillancourt, imposed liability for unforeseen consequences of otherwise criminal conduct, Lamer J. nonetheless held that mens rea was required for that consequence. Courts striking down other subsections in s. 213 are following Lamer J.'s reasoning. While courts seem willing to differentiate first from second degree murder based on the underlying activity in which the accused was engaged, they have not been willing to use the same rationale to justify the initial murder conviction.

It is clear that murder is being treated as a unique offence in terms of mens rea. The only justification provided by the courts for this treatment is the special stigma discussed by Lamer J. in Vaillancourt. In practical terms this stigma may come from the mandatory minimum sentences prescribed for murder. For every other offence discussed in this paper, a trial judge retains some discretion to tailor the sentence to fit the blameworthiness of the accused. Since everyone convicted of murder must be sentenced to life, with a minimum period before parole eligibility, the courts 
are insisting that blameworthiness be assessed fully at the conviction stage. The mechanism chosen to accomplish this is the doctrine of subjective mens rea.

The Supreme Court of Canada has granted leave to hear several cases dealing with the Code's murder provisions. We must hope that the Court will clarify the nature of the special stigma of murder and whether subjective mens rea is always constitutionally required. The Court should also make clear whether murder is truly unique or whether other crimes have similar requirements. 